\title{
EGY FELSŐ-TISZA-VIDÉKI, RANGOS, HONFOGLALÓ FÉRFI SZOBRÁSZI ARCREKONSTRUKCIÓJA A TUZSÉRI TEMETŐBŐL
}

\author{
Kustár Ágnes \\ Budapest
}

Kustár Á.: Sculptural reconstruction of a prestigious Hungarian conqueror individual from the Upper Tisza region from the Tuzsér cemetery. The mature age individual excavated from the Tomb 6 of Tuzsér-Boszorkány-hegy cemetery, was a member of the prestigious Hungarian conquering communities in the Upper Tisza region. He was a taxonomically mixed European and Mongolian type. On the top of his predominantly Europid Pamirian skull, two symbolic trepanations were also visible. His paternal genetic line links him to the "Yakut subgroup", within it was classified in the Turkic-conquering cluster, whose origin dates back to the Asian Hun era. The facial reconstruction of the Tuzsér conqueror was done at the Hungarian Natural History Museum on a 3D plastic skull copy of the original skull. Using the sculptural anatomical method the thickness of the soft parts of the face was estimated based on a scientific data table. Each detail of the face was shaped according to the morphological correlations of the skull bones and soft tissues. The reconstructed facial features have a predominantly Europid appearance, but also faithfully reflect the mixed, Europid and Mongolian characteristics of the skull.

Keywords: Sculpting craniofacial reconstruction; Facial anatomy; Soft tissue thickness of a face; $3 D$ copy of the skull; Hungarian Conquest period; Conquering military elite.

\section{Bevezetés}

A múlt század végén Tuzsér határában (ma Szabolcs-Szatmár-Bereg megye) - a tiszabezdédi honfoglalás kori temető lelöhelyétől mintegy 6 km-re - a Boszorkány-hegy nevü kiemelkedésen szőlőtelepítés során honfoglalás kori sírokra bukkantak. Jósa András 1900-ban ásatást végzett a helyszínen és a korábban megbolygatott 4 sír mellett további 2 sírt tárt fel. A 6. sírban feltehetőleg egy előkelő férfi nyugodott. A halott baloldalán helyezték el egykori tegezét 5 nyílvesszővel, amelyek keskeny három élü nyílheggyel voltak felszerelve. A hatodik nyílvesszőt, amelynek hegye széles, legyező formájú volt, a tegezből kivették és arra fektették. Szintén a baloldalon helyezték el díszítetlen ezüstlemezü tarsolyát, amelyben tüzkövet és egy csontnyelü kis vaskést találtak. A sír megőrizte a halott varkocskarikáját és övfelszerelésének ezüst és bronz övvereteit, csatok és szíjvégek maradványait is. Az elhunyt fölött lelt papírvékonyságú ezüstlemezek bizonyára a halotti lepelre lehettek varrva. A honfoglalás kori értékes régészeti leletek a nyíregyházi Jósa András Múzeumba kerültek, a koponyát a Magyar Természettudományi Múzeum Embertani tárának gyüjteménye őrzi (1-2. ábra).

E leletek is bizonyítják, hogy Tuzsér területe és környéke már a honfoglalás idején is a határt alkotó gyepürendszer fontos része volt. Jósa és munkatársai csupán az addig már észlelt sírokat bontották ki, amelyek egyetlen észak-déli sorba rendeződtek. Azonban a láthatóan rangos temetőnek bizonyára jóval több sírja lehetett. Egy részüket a 
rigolírozással valószínüleg megsemmisítették, de nem lehetetlen, hogy további sírok még ma is a Boszorkány-hegy alatt vannak (Jósa 1900, Révész 1996a).

A Szabolcs és Zemplén megyék területén feltárt 10. századi temetők meglepő egyöntetűséget mutatnak. Jellemzően szinte valamennyi sír abba a kategóriába sorolható, amelyet a kutatás eddig a „nagycsaládi” vagy „,rangos középréteg” elnevezésekkel illetett. A temetők sírjainak zömében férfiak nyugodtak, mégpedig íjjal, tegezzel, lóval és nem ritkán harci baltával, szablyával felszerelt harcosok. Méltóságukat aranyozott, ezüst veretes övek jelzik, különböző rangú vezetöik pedig veretes tarsolyt vagy tarsolylemezt hordtak. E rangos közösségek nyughelyei egymástól olykor csak néhány száz méterre fekszenek, mintegy temetőcsoportokat alkotva. E temetők szerkezetüket, összetételüket, viseletüket tekintve is eltérnek a Kárpát-medence más részeinek temetőitől. Révész László véleménye szerint a zempléni és szabolcsi lelőhelyeken valamely törzsfö vagy fejedelem katonai kíséretének tagjai, azok kisebb-nagyobb rangú vezetői és családtagjaik, házi szolgáik nyugodhattak. Életükben elsődleges feladatuk a katonáskodás lehetett, gazdálkodásuk alapját pedig a Bodrogköz, Rétköz, Taktaköz dús füvü ártéri legelöin folytatott nagyállattartás jelentette (Nepper és Révész 1990).

A Felső-Tisza-vidéki rangos honfoglaló temetkezések sorába tartozott a TuzsérBoszorkány-hegyről előkerült temetőrész. A 6. sírból származó koponyán Éry Kinga végzett embertani vizsgálatot (Éry 1977). Éry megállapította, hogy a maturus korú férfi taxonómiailag kevert, europid és mongolid jegyeket is mutató koponyáján túlsúlyban voltak az europid pamíri jellegek. A fogakon és a homlokcsont halántéki részén baloldalt látható zöld patina a halotti lepelre varrt szemfedő nyoma lehetett. A fejtetőn egy nagyobb mandula alakú $(50 \times 37 \mathrm{~mm})$ és egy (vagy két) kisebb kerek, jelképes trepanációt figyelt meg (1-3. ábra). A koponyaméretekből számított jelzők szerint az agykoponya nagyon rövid (8/1: hyperbrachykran), közepesen magas (17/1: orthokran) ill. alacsony (17/8: tapeinokran). A homlok keskeny (9/8: stenometop), a felsőarc közepesen széles (48/45: mesen). A szemüreg közepes (52/51: mesokonch), az orrüreg keskeny (54/55: leptorrhin). A koponya alakja norma verticalisban spheroid. A glabella +2 , a protuberantia occipitalis externa +2 , a fossa canina pedig 3-as fokozatú. A nyakszirt mérsékelten ívelt. Az orrprofil hullámos lefutású (concavo-convex), az orbita lekerekített. A maxillán mérsékelt alveolaris prognathiát figyelt meg.

Nemeskéri és munkatársai kutatása szerint a 10. századi jelképesen trepanált koponyák időrendi megoszlása már önmagában is arra utal, hogy a 10. századi honfoglaló magyar temetőkben ez a jelenség jellegzetes és szinte etnikai meghatározó értékü (Nemeskéri és mtsai 1960). Tanulmányukban hangsúlyozzák, hogy a pamíri és turanid komponensek gyakorisága különösen szembetűnő a Duna-Tisza közéről származó honfoglalás kori jelképesen trepanált koponyák között, amint arra már Lipták is rámutatott (Lipták 1957). Ugyanez tapasztalható az Alföld északkeleti peremén talált leleteknél.

E tipológiai vonatkozás során utalnak arra is, hogy a jelképes trepanációk elsődlegesnek meghatározott típusai (alak, hely és méret tekintetében) is e tipológiai elemeknél találhatók meg leginkább. 

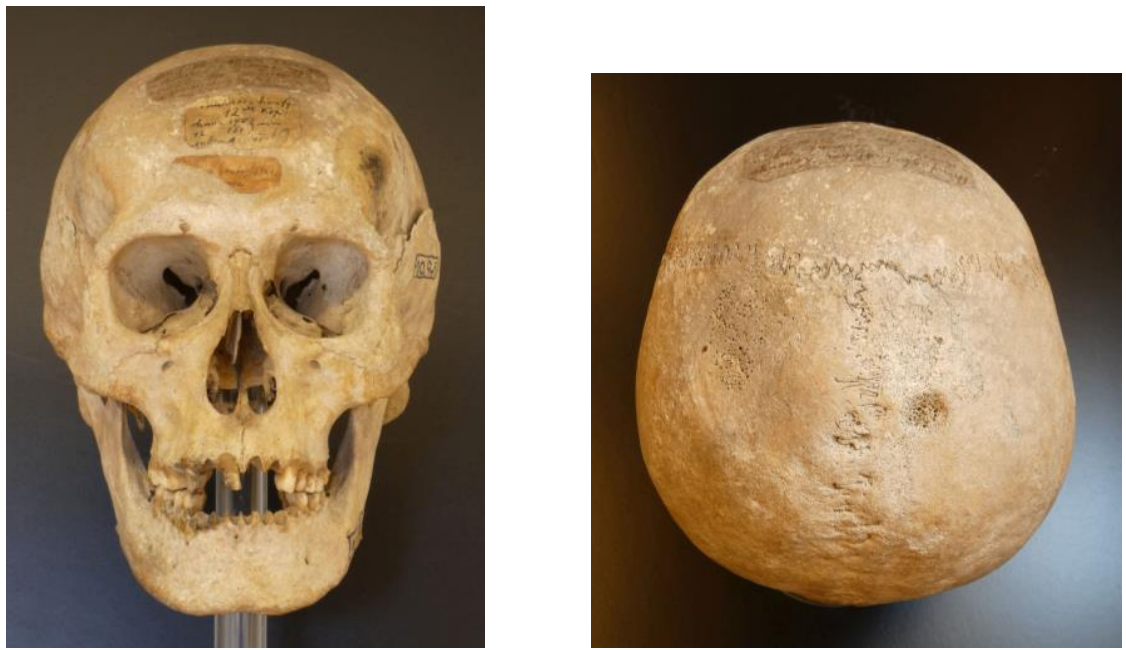

1. ábra: Honfoglaló férfi koponyája, 2. ábra: Jelképes trepanációk a Tuzsér-Boszorkány-hegy 6. elölnézet (Tuzsér-Boszorkány-hegy, 6. sír).

Fig. 1: Skull of a Hungarian conqueror individual, frontal view (Tuzsér-Boszorkány-hegy, Tomb 6).

sír koponyáján. A bal falcsonton a tabula externát és a diploét érintő mandulaalakú bemetszés; a jobb falcsonton a nyílvarrathoz közel, a koronavarrattól $32 \mathrm{~mm}$-re, $15 \mathrm{~mm}$ átmérőjü, $4 \mathrm{~mm}$ mély gyógyult kerek csontseb.

Fig. 2: Symbolic trepanations on the skull of the Tomb 6 of Tuzsér-Boszorkány-hegy. An almond-shaped incision affecting tabula externa and the diploe on the left parietal bone; and a $4 \mathrm{~mm}$ deep healed round bone scar, $15 \mathrm{~mm}$ in diameter on the right parietal bone that is located close to the sagittal suture, $32 \mathrm{~mm}$ behind the coronal suture.

Fóthi Erzsébet (2014) a magyar etnogenezist kutató, klasszikus embertani vizsgálatokon alapuló átfogó tanulmányában megerősíti Éry Kinga korábbi megállapítását (Éry 1982), ami szerint honfoglaló magyaroknak van népvándorlás kori kötődése az Észak-pontuszi és Volga-Káma vidéki régióban. Ugyanakkor Fóthi felhívja a figyelmet a Közép-ázsiai és Dél-szibériai 5-7. századi nomád türk törzsekkel való antropológiai párhuzamokra is. A lehetséges kapcsolatot, a honfoglalók apai genetikai vonalainak vizsgálati eredményei is alátámasztják Fóthi és munkatársai (2020) újabb tanulmányában. Vizsgálatuk fókuszába az ún. klasszikus honfoglaló férfi leleteket helyezték, amelyek nagy valószínüséggel a magyarok első nemzedékét reprezentálják a Kárpát-medencében. A vizsgálati anyag többségét a Felső-Tisza-vidékről választották - köztük a Tuzsérboszorkány-hegyi koponyát, mivel nagy valószínüséggel itt volt a magyarok első fejedelmi székhelye a 10. század első felében (Révész 1996b). A honfoglaló katonai elitet reprezentáló minta meglepően heterogénnek bizonyult a haplocsoport-eloszlás tekintetében is. A vizsgált egyének nagy hányada (19 egyénből 7!) az N3a-Tat haplocsoport két alcsoportjába volt sorolható. Közülük két minta, a Tuzsér-boszorkányhegyi és az örménykúti 52/50. sírban nyugvó férfi az N3a2-M2118 csoport (régi terminológia szerint N1c-M2118), Észak-eurázsiai jakutokra jellemző alcsoportjába tartozott. Ez az alcsoport 70-90\%-os gyakorisággal fordul elő a közép-szibériai türk nyelvü jakutok között, 50\% a szomszédos türk nyelvü dolgánok és tunguz nyelvü evenkik 
között, míg a hantiknál 10\%, más népek körében pedig 5\% alatti a gyakorisága (Ilumäe és mtsai 2016). Fóthi és munkatársai (2020) az N3a2 csoporton belül három nagyobb klasztert különítettek el - jakut klaszter, obi-ugor klaszter és türk-honfoglaló klaszter amelyek közül a tuzséri és az örménykúti mintát a türk-honfoglaló klaszterbe sorolták. A klaszter korát STR (Short Tandem Repeat) alapon 1970-2070 \pm 690 évre becsülték, így annak kialakulása az ázsiai hun korba nyúlik vissza. Az eredmény alapján valószínüsítik, hogy a tuzséri és örménykúti lelet a honfoglalók türk/hun kapcsolatát támasztja alá.

A régészeti kutatás mára egyetért abban, hogy nagy valószínüséggel a Felső-Tiszavidék volt a magyarok első fejedelmi székhelye a 10. század első felében. Így a Szabolcs és Zemplén megyék területén feltárt 10. századi temetőkben valamely törzsfö vagy fejedelem katonai kíséretének tagjai, azok kisebb-nagyobb rangú vezetői és családtagjaik, házi szolgáik nyugodhattak. Bár az ún. klasszikus honfoglaló férfi leleteket régészeti, antropológiai és genetikai szempontból egyaránt számos kutató elemezte, arcrekonstrukció még alig néhány koponyáról készült a régióból. A Tuzsértól mintegy 40 km-re fekvő karosi vezéri temetkezések közül mindössze három egyénről (47. női sír; 52. és 60. férfi sír) készített arcrekonstrukciót Skultéty Gyula (Neparáczky és mtsai 2018). A Dél Alföldön, Bács-Kiskun megye területéről származó leletek közül csupán a Ladánybene-benepusztai idős férfiről (Ltsz. 1432; Kustár és Skultéty 1996) és HartaFreifelt temetőjéből két egyénről (15. női sír és 23. férfi sír) készült arcrekonstrukció (Kustár 2003, 2005). A tuzséri temető 6. sírjában nyugvó, előkelő férfiról a régészeti, embertani és genetikai megfigyelések egyaránt rendelkezésre állnak. Munkánk célja, hogy a komplex ismeretanyag birtokában, tudományos arcrekonstrukciót készítsünk a honfoglaló magyar elit egyik tipikus képviselőjéről.

\section{Anyag és módszer}

A Tuzsér-Boszorkány-hegyen feltárt temetőrész 6. sírjából (Ltsz. 10945) származó koponyáról (1-3. ábra) a Magyar Természettudományi Múzeumban készült arcrekonstrukció.

$\mathrm{Az}$ eredeti koponyáról 3D mủanyag koponyamásolatot készítettünk a Varinex Zrt. közremüködésével. A nyers koponya CT-felvételekből elöször 3D virtuális (számítógépes) rekonstrukció készült, majd a virtuális koponyamodellből SLS eljárással (Selective Leser Sintering) állították elő a kézbe vehető müanyag koponyamásolatot, amelyen elvégeztük a szobrászi rekonstrukciót (4. ábra).

Az arcrekonstrukció lehetővé teszi a múltban élt személyek arcvonásainak közvetlen megjelenítését. Az alapja a koponya és az arc anatómiai ismeretén túl az egyedi karaktervonások tanulmányozása a csontokon (Sobotta 1990). Az arcrekonstrukciós módszer lényege, a mimikai és a rágóizmok visszaépítése a koponyára a csontok izomtapadási felszínei alapján (Sjøvold 1981, Árpás 2006, Kustár és Árpás 2008; 5. ábra). Az izmok és lágyszövetek vastagságát az izomtapadási felszínek fejlettségi foka alapján becsültük a koponya 45 mérőpontján Röhrer-Ertl és Helmer (1984) táblázatba foglalt adatai alapján (Kustár és Skultéty 1996). Az antropometriai és morfológiai jellegeket az eredeti koponyán tanulmányoztuk. Az arcvonásokat a koponyacsontok és az arcfelszín formai összefüggései alapján mintáztuk meg Geraszimov (1949, 1971), Prag és Neave (1997), valamint Taylor (2001) módszertani útmutatóit követve.

$\mathrm{Az}$ arcrekonstrukció „Szobrászi fázisában” megmintáztuk az arc részleteit, harmonikussá téve a formákat. Ez volt a legaprólékosabb, egyben leghosszadalmasabb 
része a munkánknak. A szobrászi formarend alkalmazása segítette az arcrészletek harmonikus illesztését és szerves egésszé formálását (6. ábra).

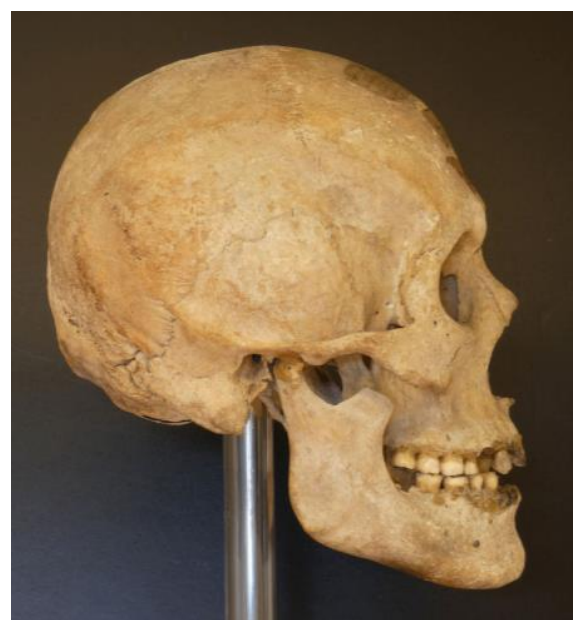

3. ábra: Honfoglaló férfi koponyája a TuzsérBoszorkány-hegy 6. sírból, oldalnézet.

Fig. 3: The skull of a conquering man from the Tomb 6 of Tuzsér-Boszorkány-hegy, lateral view.

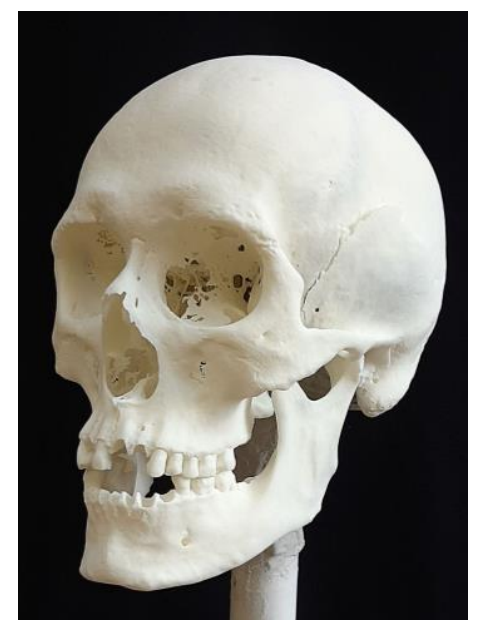

4. ábra: Rapid Prototyping (RP) eljárással előállított mủanyag koponyamásolat, félprofil.

Fig. 4: Plastic skull copy produced by Rapid Prototyping (RP) method, half profile view.

\section{Vizsgálati eredmények és megvitatásuk}

A koponya jó megtartású, erőteljes, férfias. A homlok domború, hátrafutó és széles, ám a frontotemporale mérőpontoknál hirtelen összeszükülő. A nyakszirt enyhén ívelt, erős izomtapadási felszínekkel. A processus mastoideus nagy, vaskos (1-2. ábra). A rekonstruált arcon is megmutatkoznak a koponya jellegzetességei és arányai. Az egészarc elölnézetben magas, keskeny. A nyak erőteljes, izmos. A homlok széles, domború, a szemöldökív erőteljes. Az arc oldalnézetben erösen tagolt. A homlok hátrahajló, domború, az erősen kiemelkedő glabella mellett az orrgyök mélynek hat (7-9. ábra). A járomcsont magas, széles, felszíne sima. A járomív karcsú, közepesen széles, kifelé ívelö. A fossa canina sekély, aszimmetrikus (a baloldali kissé mélyebb). Az arc karakterének kialakításában hangsúlyos a közepesen széles középarc és a kiszélesedő járomtájék. Az orrgyök keskeny és sekély. Az orrcsontok is keskenyek, a középvonalban kissé „összecsippentett” formájúak és kiemelkedők (1.b fokozat). Az orrhát közepesen kiemelkedő, az orrprofil enyhén hullámos lefutású. Az apertura piriformis keskeny, anthropin. Az orrtövis Broca szerinti 3. fokozatú, széles vályú alakú, kettéosztott csúcsban végződik. Iránya vízszintes, ami előremutató orrcsúcsra utal. A rekonstruált arcon az orrgyök és az orrhát keskeny, az orrszárnyak közepesen szélesek. Az orrhát közepesen kiemelkedő, enyhén ívelt, az orrcsúcs előreirányuló, hegyesedő. Az orbita közepes, lekerekített. Alsó pereme megvastagodott, kissé előreugró. A szemrés iránya megközelítőleg vízszintes, a szemüreg felső peremének enyhe visszahajlása következtében a szemhéjakat nem takarja szemredő. Mindkét állcsonton mérsékelt 
mesognathia figyelhető meg. A fogazat ép, a post mortalisan hiányzó frontfogakat (maxilla: j2, 4; b1, 2; mandibula j1, 3; b1-4) viaszból pótoltuk. A fogak közepes méretüek, a felső caninus-ok kissé kiállók. A fogsorív széles, parabola alakú. A rekonstruált felsőajak és az áll magas. Az ajkak közepesen teltek és mérsékelten előreállók. A felsőajak kissé előrébb áll az alsónál.

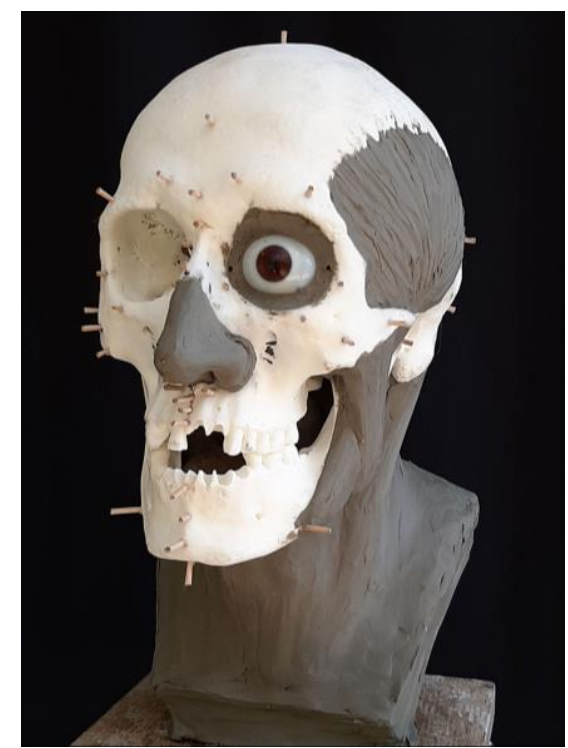

5. ábra: Készülő arcrekonstrukció a lágyrész-vastagság mérő tövisekkel és a rágóizmokkal. Már látható a külső orr alapkaraktere és a szemgolyó elhelyezkedése. Félprofil (Tuzsér-

$$
\text { Boszorkány-hegy, 6. sír). }
$$

Fig. 5: Facial reconstruction in progress with soft tissue thickness markers and chewing muscles. The basic character of the external nose and the location of the eyeball are already visible. Half profile view (Tuzsér-Boszorkány-hegy, Tomb 6).

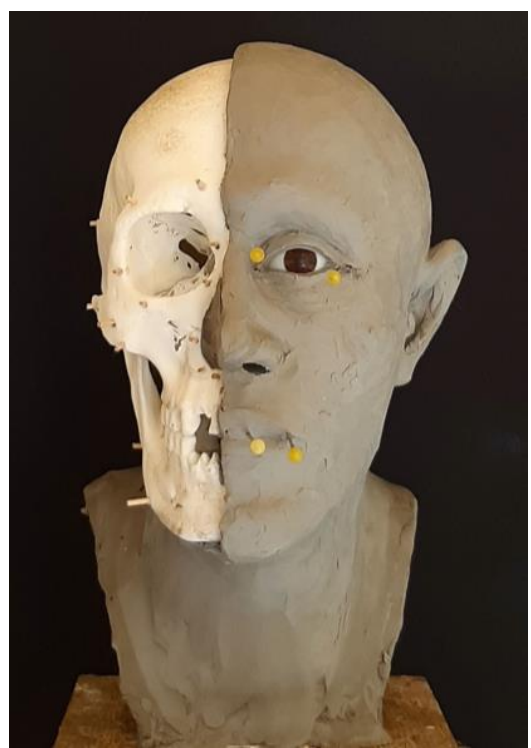

6. ábra: A félkész arcrekonstrukción a koponya egyik fele még látható. Ebben a fázisban ellenőrizzük a csont és lágyrész formák morfológiai megfelelését. A szem-és szájzugok helyét hosszú tük jelölik. Elölnézet (Tuzsér-Boszorkány-hegy, 6. sír).

Fig. 6: One half of the skull is still visible on the half-finished facial reconstruction. In this phase, the morphological correspondence of the bone and soft tissue shapes is checked. The location of the corners of the eyes and mouth is indicated by long needles. Front view (Tuzsér-Boszorkány-hegy,

Tomb 6).

Az állcsúcs széles, lekerekített, gyengén kettéosztott. Az áll a symphysisnél magas, a mentum fordított $\mathrm{T}$ alakú, előreugró. A ramus magas, széles, a corpus vaskos. Az angulus mandibulae erőteljes, de lekerekített formájú, mérsékelt reliefekkel. Az rekonstrukción az állcsúcs széles, lekerekített forma, az állkapocsszöglet nem túl hangsúlyos. Oldalnézetben az áll magas, az állcsúcs körvonala ívelt, kissé előreugró. A fülek méretére és alakjára utaló támpontok nem olvashatók le a koponyáról, ezért azok megmintázásánál az általános anatómiai felépítésre és az arc formáival való harmónia kialakítására törekedtünk (7-9. ábra). 


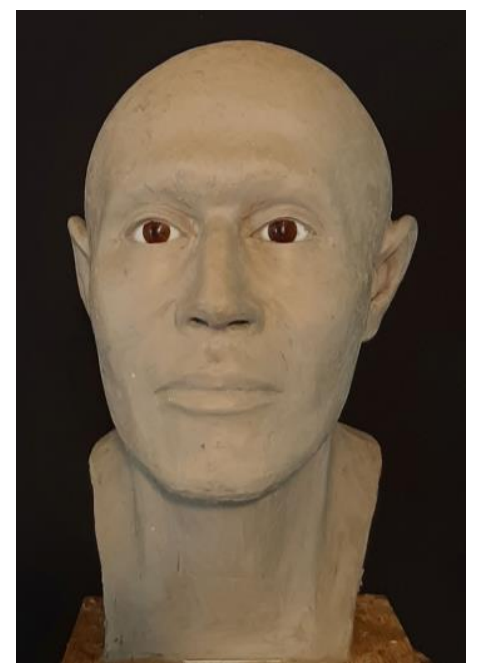

7. ábra: Az elkészült nyers arcrekonstrukció, elölnézet (Tuzsér-Boszorkány-hegy, 6. sír). Fig. 7: Completed raw facial reconstruction, frontal view (Tuzsér-Boszorkány-hegy, Tomb 6).

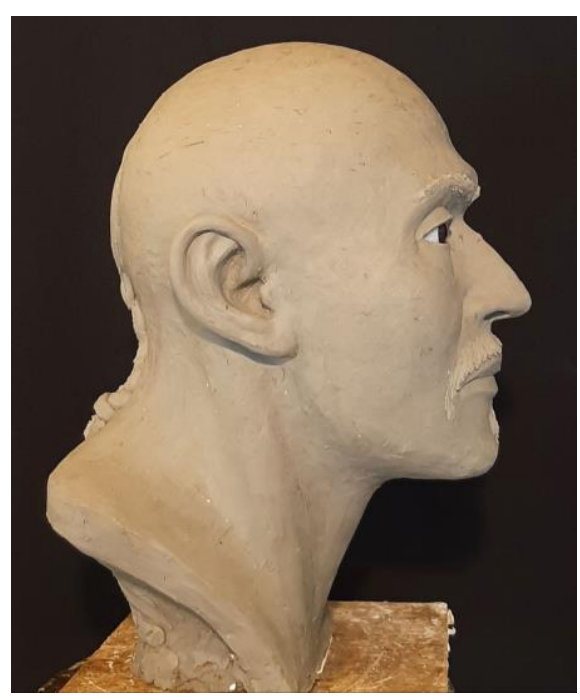

8. ábra: Arcrekonstrukció hajjal és bajusszal, oldalnézet (Tuzsér-Boszorkány-hegy, 6. sír). Fig. 8: Facial reconstruction with hair and moustache, lateral view (TuzsérBoszorkány-hegy, Tomb 6).

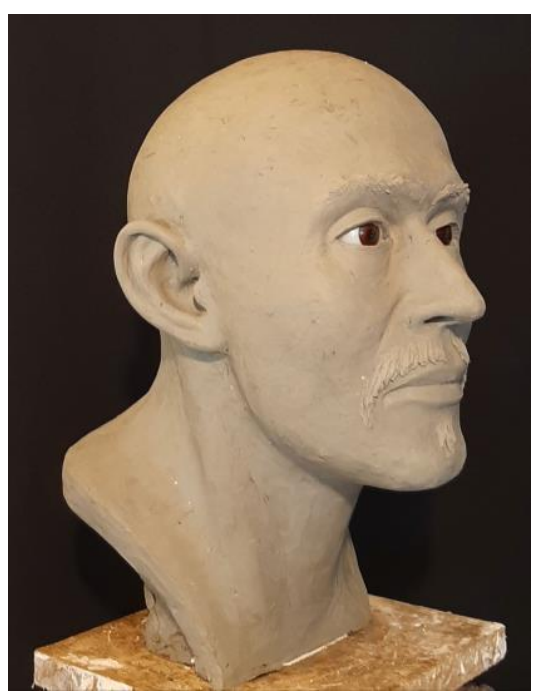

9. ábra: Arcrekonstrukció feltételezett haj és bajuszviselettel, negyed profil (Tuzsér-Boszorkány-hegy, 6. sír).

Fig. 9: Facial reconstruction with presumed hair and moustache wear, quarter profile (TuzsérBoszorkány-hegy, Tomb 6).

A haj és arcszőrzet egyedi jellegzetességeiről szintén nem nyújt támpontot a koponya, ezért azok megjelenítésében a forrásokra hagyatkoztunk. Ismeretes, hogy a 9-10. századi nomád harcosok a fejük tetejét borotválták, míg a nyakszirt és a halánték hajtincseit egy 
vagy több varkocsba fonták (8. ábra). A sír megörizte a halott varkocskarikáját, ezért egy, a nyakszirten összefogott varkocsot alakítottunk ki. Az arcszörzet a mongolid és europomongolid férfiak esetében általában gyér, ezért csak jelzésszerủen mintáztuk meg a ritkás, lefelé ívelő bajuszt. Bár a koponya alapján nem eldönthetö, hogy az egykori személy kövér volt vagy sovány, feltételeztük, hogy a rangos férfi táplálékban sem szenvedett hiányt. Így az arcformákat a közepes tápláltságnak megfelelően alakítottuk ki. Az arcrekonstrukcióhoz felhasznált lágyrész-vastagsági adatokat az 1. táblázatban tesszük közzé.

1. táblázat. Tuzsér-Boszorkány-hegy 6. sír lágyrész-vastagság adatai a koponyán ("fokozatok 1: igen gracilis, 2: kevésbé gracilis, 3: erős, 4: igen erős; Kustár és Skultéty 1996 cit. Röhrer-Ertl és Helmer 1984 táblázata alapján).

Table 1. Soft tissue thickness data on the skull of Tomb 6, from Tuzsér-Boszorkány-hegy site ('degrees -1 : very gracile, 2 : slightly gracile, 3 : robust, 4 : very robust by Kustár és Skultéty 1996 cit. Röhrer-Ertl és Helmer 1984).

\begin{tabular}{|c|c|c|}
\hline $\begin{array}{l}\text { Mérőpont - } \\
\text { Osteometric points }\end{array}$ & $\begin{array}{l}{ }^{*} \text { Fokozat - } \\
\text { Degree }\end{array}$ & $\begin{array}{c}\text { Lágyrész-vastagság - } \\
\text { Soft tissue thickness (mm) }\end{array}$ \\
\hline Bregma (b) & 3 & 6 \\
\hline Metopion (m) & 3 & 6 \\
\hline Glabella $(\mathrm{g})$ & 3 & 8 \\
\hline Nasion (n) & 3 & 6 \\
\hline Rhinion (rhi) & 3 & 3 \\
\hline Philtrum (ph) & 3 & 9 \\
\hline Labiomentale (lab) & 3 & 10 \\
\hline Pogonion (pog) & 3 & 11 \\
\hline Gnathion (gn) & 3 & 9 \\
\hline Arcus superior medialis (acm) & 3 & 9 \\
\hline Arcus superior lateralis (acl) & 3 & 7 \\
\hline Ectoconchion (ek) & 3 & 3 \\
\hline Orbitale (or) & 3 & 4 \\
\hline Dacryon (da) & 3 & 4 \\
\hline Lacrimale (la) & 3 & 3 \\
\hline Lateral apertura piriformis (lat. ap) & 3 & 3 \\
\hline Alare (al) & 3 & 3 \\
\hline Subspinale laterale (ss. lat) & 1 & 9 \\
\hline Caput mandibulae (cap) & 3 & 5 \\
\hline Gonion (go) & 3 & 6 \\
\hline Zygion (zyg) & 3 & 7 \\
\hline Facies zygomaticus (fac. zyg) & 3 & 7 \\
\hline Sutura zygomatico-maxillaris (sut. zyg. max) & 3 & 5 \\
\hline Processus mastoideus (mast) & 3 & 4 \\
\hline Lambda (l) & 3 & 6 \\
\hline Opisthocranion (op) & 3 & 8 \\
\hline Ajakvastagság - Lip thickness & 3 & 12 \\
\hline Ajakmagasság - Lip height & - & 6 \\
\hline $\begin{array}{l}\text { Alsó mandibularis szög (alsó mb. szög) - Lower } \\
\text { mandibular angle }\end{array}$ & 1 & 8 \\
\hline
\end{tabular}




\section{Következtetések}

Ritka az olyan ép koponya lelet, amely a legtöbb ismert, a honfoglalókra tipikusan jellemző attribútummal rendelkezik, ugyanakkor szobrászi arcrekonstrukció készítésére is alkalmas. A tuzséri 6. sírban nyugvó férfi temetkezési rítusa és tárgyi hagyatéka alapján minden bizonnyal a közösség rangos tagja lehetett. A halotti lepelre varrt ezüst szemfedél és a jelképes trepanációk megléte kultikus vonatkozásban is a honfoglaló magyarsághoz köti a tuzséri férfit. Antropológiai tekintetben a honfoglalók vezető rétegére jellemző kevert europid - elsősorban pamíri - és mongolid morfológiai jegyeket is mutatott. Apai genetikai vonala a ,jakut alcsoporthoz”, azon belül a türk-honfoglaló klaszterhez köti, amelynek kialakulása az ázsiai hun korba nyúlik vissza. A genetikai eredmények azt mutatják, hogy a tuzséri rangos férfi a magyar törzsszövetség türk/hun ágának egyik tipikus képviselője lehetett. A koponya kevert, europid és mongolid morfológiai jegyei jellegzetes karaktert kölcsönöznek a rekonstruált arcnak. A döntően europid koponyaalkatnak köszönhetően az arcprofil erősen tagolt. Europid jelleg a homlok vonalából erösen kiemelkedő glabella és szemöldökív, továbbá a keskeny és mély orrgyökböl induló kiálló keskeny orrhát. A vízszintes szemrés és a hiányzó szemredő szintén az europidokra jellemző. A koponya enyhe mongoloid vonásai - a széles, lapos, magas járomtájék; a kitöltött fossa canina; az orrcsontok formája; a szemüreg alsó peremének megvastagodott elöreugrása - összességében a rekonstruált arcnak is enyhe mongoloid jelleget kölcsönöznek. Különösen a magas, közepesen széles középarc és a kiálló járomtájék meghatározó az arc karakterében.

Az elkészült szobrászi arcrekonstrukciónak köszönhetően megismerhetjük a FelsőTisza-vidéken megtelepedett honfoglaló magyar katonai elit egyik tipikus képviselőjének arcvonásait.$$
* * *
$$

Tanulmányomat szeretettel ajánlom Dr. Marcsik Antóniának és Prof. Dr. Gyenis Gyulának 80. születésnapja alkalmából. Kívánom, hogy jó egészségben, még hosszú évekig sikeresen folytathassák kutatómunkájukat!
}

Köszönetnyilvánítás: A tanulmány megjelenését az „Árpád-ház Program (2018-2023), Tudományos szakmai alprogramok: V.1. Az Árpád-kori magyarság embertani-genetikai képe” c. pályázata támogatta.

\section{Irodalom}

Árpás, K. (2006): III. Béla király és Chatillon Anna arcrekonstrukciója. Folia Anthrop., 4: 5-19.

Éry, K. (1977): Embertani adatok a Felső-Tiszavidék X. századi népességéhez. Anthrop. Közl., 21 : $15-30$.

Éry, K. (1982): Újabb összehasonlító statisztikai vizsgálatok a Kárpát-medence 6-12. századi népességeinek embertanához. VMMK, 16: 35-85.

Fóthi, E. (2014): A Kárpát-medence 6-11. századi történetének embertani vonatkozásai. In: Sudár, B., Szentpéteri, J., Petkes, Z., Lezsák, G., Zsidai, Zs. (Szerk.) Magyar östörténet, Tudomány és hagyományőrzés. MTA Bölcsészettudományi Kutatóközpont, Budapest. pp. 151-168.

Fóthi, E., Gonzalez, A., Fehér, T., Gugora, A., Fóthi, Á., Bíró, O., Keyser, C. (2020): Genetic analysis of male Hungarian conquerors: European and Asian paternal lineages of the conquering Hungarian tribes. Archaeol. Anthropol. Sci., 12: 31. DOI: 10.1007/s12520-019-00996-0

Geraszimov, M.M. (1949): Bases of the facial reconstruction. Nauka, Moscow. 
Geraszimov, M.M. (1971): The face finder. Hutchinson and Co, London.

Ilumäe, A.M., Reidla, M., Chukhryaeva, M., Järve, M., Post, H., Karmin, M., Saag, L., Agdzhoyan, A., Kushniarevich, A., Litvinov, S., Ekomasova, N., Tambets, K., Metspalu, E., Khusainova, R., Yunusbayev, B., Khusnutdinova, E.K., Osipova, L.P., Fedorova, S., Utevska, O., Koshel, S., Balanovska, E., Behar, D.M., Balanovsky, O., Kivisild, T., Underhill, P.A., Villems, R., Rootsi, S. (2016): Human Y chromosome haplogroup N: A non-trivial time-resolved phylogeography that cuts across language families. Am. J. Hum. Genet., 99: 163-173. DOI: 10.1016/j.ajhg.2016.05.025

Jósa, A. (1900): Emlékek a honfoglalás korából. Arch. Ért., 20: 214-224.

Kustár, Á. (2003): Harta-Freifelt lelőhelyről származó honfoglaló magyar nő (15. sír) és férfi (22. sír) arcrekonstrukciója. MTM Arcrekonstrukciós katalógus. http://www.nhmus.hu/hu/arcreko_katalog

Kustár Á. (2005): Humán morfológiai variációk az arcon és a koponyán. A koponya és az arc morfológiai összefüggéseinek alkalmazása a plasztikus arcrekonstrukcióban. Anthrop. Közl. 46; 67-74.

Kustár, Á., Árpás, K. (2008): Facial reconstructions of the 18th Century mummies from Vác, Hungary. In: Atoche Pena, P., Rodriguez, M.C., Ramirez Rodriguez, M.A. (Eds) Mummies and science. World Mummies Rresearch. Proc. VIth World Congress on Mummy Studies. Academia Canaria de la Historia Ayuntamiento de Teguise, Santa Cruz de Tenerife. pp. 487-495.

Kustár, Á., Skultéty, Gy. (1996): A benepusztai honfoglaláskori férfi koponyarekonstrukciója. Savaria, 22(3): 179-190.

Lipták, P. (1957): Awaren und Magyaren im Donau-Theiss Zwischenstromgebiet. Acta Arch. Hung., 8: 199-259.

Nemeskéri, J., Éry, K., Kralovánszky, A. (1960): A magyarországi jelképes trepanáció. Anthrop. Közl., 4: 3-32.

Neparáczki, E., Maróti, Z., Kalmár, T., Kocsy, K., Maár, K., Bihari, P., Nagy, I., Fóthi, E., Pap, I., Kustár, Á., Pálfi, G., Raskó, I., Zink, A., Török, T. (2018): Mitogenomic data indicate admixture components of Central-Inner Asian and Srubnaya origin in the conquering Hungarians. PLoS One, 13(11): e0208295. DOI: 10.1371/journal.pone.0208295

N. Nepper, I., Révész, L. (1990): Etelközböl a Kárpát-medencéig. A honfoglalók legújabb leletei. Kiállítási katalógus. A Déri Múzeum és a Herman Ottó Múzeum kiállítása. Déri Múzeum Herman Ottó Múzeum, Debrecen.

Prag, J., Neave, R. (1997): Making faces. Using forensic and archaeological evidence. The Trustees of the British Museum. British Museum Press, London.

Révész, L. (1996a): „Őseinket felhozád...” In: Fodor, I. (Szerk.) A honfoglaló magyarság. Kiállítási katalógus. Magyar Nemzeti Múzeum, Budapest.

Révész, L. (1996b): A karosi honfoglaláskori temetök. Régészeti adatok a Felsö-Tisza vidék X. századi történetéhez. Magyarország honfoglaláskori és Árpád-kori leletei I. Herman Ottó Múzeum - Magyar Nemzeti Múzeum, Miskolc.

Röhrer-Ertl, O., Helmer, R. (1984): Zu Stand und Möglichkeiten der Erneut modifizierten Kollmann-Methode. Gegenbaurs Morph. Jahrb., 130: 369-396.

Sjøvold, T. (1981): Árpás anatomical method for face reconstruction. Ossa, 7: 203-204.

Sobotta, J. (1990): Atlas of Human Anatomy. Urban \& Schwarzenberg, Munich.

Taylor, K.T. (2001): Forensic Art and Illustration. CRC Press Boca Raton, London, New York, Washington D.C.

$\begin{array}{ll}\text { Levelezési cím: } & \text { Kustár Ágnes } \\ \text { Mailing address: } & \text { Budapest } \\ & \text { Hungary } \\ & \text { agnes.kustar@gmail.com }\end{array}$

